\title{
Rosemary and Oregano Essential Oils as Natural Antioxidant to Preserve Pistachio Puree
}

\author{
Eda Adal and Sami Eren \\ Department of Food Engineering, Gaziantep University, Osmangazi Mahallesi, Üniversite Blv., Şehitkamil 27310, Gaziantep, Turkey
}

\begin{abstract}
In this study, the effect of adding essential oil from different plants on prolonging the shelf life of pistachio puree was investigated. For this purpose, Rancimat method, which is one of the accelerated shelf-life test (ASLT) methods, was used to determine the effect of oregano (OO) and rosemary (RO) essential oils on the oxidative stability of pistachio puree. Butylated hydroxyanisole (BHA) and the control sample were used for the comparison. Concentrations used for essential oils and synthetic antioxidants were 150,300 and $600 \mathrm{ppm}$ and $150 \mathrm{ppm}$, respectively. The conductivity was followed at three temperatures, 110,120 and $130{ }^{\circ} \mathrm{C}$, with the addition of essential oils and BHA to pistachio puree during ASLT. Pistachio puree with essential oils showed protection against the lipid oxidation process. As the temperature increased induction time was significantly decreased during ASLT $(p<0.05)$. The same concentrations of essential oils and BHA were also added into pistachio puree to observe the change in peroxide value (PV) and free fatty acid (FFA) value under normal storage temperatures 15,25 and $40{ }^{\circ} \mathrm{C}$. The PV and FFA increase were lower in RO, OO and BHA added pistachio puree samples during 8-month storage $(p<0.05)$. Six hundred $(600)$ ppm of RO added sample had an antioxidative effect as much as $150 \mathrm{ppm}$ BHA added sample for both ASLT and normal storage conditions. These essential oils could be used as natural antioxidants in foods with high lipid content increasing the shelf life of these products.
\end{abstract}

Key words: Pistachio puree, lipid oxidation, antioxidant, oregano, rosemary, essential oil, BHA, stability.

\section{Introduction}

Pistachio is one of the most important nuts in the world due to its high nutritional value and unique flavor as a snack and a food ingredient. Turkey is one of the leading countries that produce pistachio nuts with an annual output of 128,000 tons [1]. So, pistachio nuts are of great economic value for Turkey.

Pistachios are generally marketed as split for snack food. Unsplit nuts are used for processing. The food industry uses pistachios for cakes, biscuits, pies, candies, ice cream and pistachio butter [2]. They are also used as the main ingredient of many Turkish desserts. Pistachio puree, the main material of this study, is made by pasting roasted pistachio kernel and used as filling material or additive in pastry, cookery, and confectionery.

Corresponding author: Eda Adal, $\mathrm{PhD}$, research assistant, research fields: functional food, encapsulation, fats and oils, oxidation.
The most important problem of pistachio puree that has a high amount of oil content (50-60\%) and less water activity $(0.2-0.3 \%)$ is lipid oxidation. Such oxidation leads to significant loss of food's nutritional value since it involves a loss of vitamins and essential fatty acids. It also affects the food's sensory quality, changes in color, texture, and taste, which shortens its shelf-life and can result in rejection on the part of consumers [3].

In the food industry, the rate of auto-oxidation is reduced by freezing, refrigeration, packaging under inert gas in the absence of oxygen and vacuum packaging [4]. In cases where these methods are neither economic nor practical from the nutritional and technological points of view, it is highly desirable to control oxidation by the addition of antioxidants, inhibitory substances that do not reduce food quality [5].

Because of health concerns surrounding synthetic antioxidants, there has been an increasing interest in 
natural antioxidants as agents for enhancing the shelf life of foods. Many sources of antioxidants of a plant origin have been studied in recent years. Among these, many aromatic plants and spices have been shown to be effective in retarding the process of lipid peroxidation $[6,7]$.

The aim of this study was to investigate the availability of usage of rosemary (Rosmarinus officinalis L.) and oregano (Origanum onites L.) plant essential oils, two spice plants widely produced in Turkey, on prolonging the shelf life of pistachio puree. For this purpose, the essential oils were added to pistachio puree with different concentrations. The synthetic antioxidant, Buthylated hydroxyanisole (BHA), and control sample were used for comparison. The oxidative stability values of pistachio puree samples with or without antioxidants were provided by the Rancimat method, which is one of the accelerated shelf-life test (ASLT) methods. The effect of natural antioxidants on the change in peroxide value and the free fatty acid (FFA) value was followed at normal storage conditions of pistachio puree oil of samples.

\section{Materials \& Methods}

\subsection{Materials}

The main material pistachio puree was obtained from the Asım Saml Agricultural Products Export, Import and Trading, SA, (Gaziantep, Turkey). Pistachio puree was made using roasted $\left(130-135^{\circ} \mathrm{C}\right)$ pistachio kernels, mawardi (Nizip, August 2010 crop) type, $17 \mathrm{~mm}$ length, $8 \mathrm{~mm}$ height and $7 \mathrm{~mm}$ width in size.

The essential oils from oregano, Origanum onites L., and rosemary, Rosmarinus officinalis L. plants were supplied from TIKTA A.Ş., Tarımsal İklimleme ve Teknolojik Araştırmalar Anonim Şirketi, (Ankara, Turkey). BHA was purchased from Merck Chemical Co. (Darmstadt, Germany). The analysis of the essential oil of rosemary performed using Agilent 7890 A GC and Agilent 5975 C VL MSD with triple-axis detector equipped with Agilent HP Innowax
$(60 \mathrm{~m} \times 0.25 \mathrm{~mm}$ i.d.; film thickness $0.25 \mu \mathrm{m})$ column.

All chemicals used in this study were of analytical grade and purchased from Merck Chemical Co. (Darmstadt, Germany).

\subsection{Methods}

2.2.1 Preliminary Determination of Antioxidant Activity

Before the study, pistachio oil was obtained from the roasted pistachio nuts by cold pressing (Kardeşler press, İstanbul). One hundred and fifty (150) ppm, 300 ppm and $600 \mathrm{ppm}$ of essential oils and BHA were added to roasted pistachio oil samples to determine the antioxidant activity of essential oils. Control oil was used for comparison. In order to obtain induction time, a Rancimat device Methrohm 743 (Herisau, Switzerland) was used. Three (3) g of each sample was placed into a Rancimat standard tube in duplicate and subjected to the normal operation of the test by applying $120^{\circ} \mathrm{C}$ and a flow of air of $20 \mathrm{~L} / \mathrm{h}$. Sixty (60) $\mathrm{mL}$ of ultra-distilled water was put in each measuring vessel. The endpoint of the induction time was characterized by the sudden increase of water conductivity, due to the dissociation of volatile carboxylic acids.

The antioxidant activity index (AAI) was calculated from the measured induction time according to the following formula [3].

AAI $=$ induction period of oil with antioxidant/induction time of pure oil

2.2.2 Sample Preparation and Storage Conditions

The essential oils from rosemary ( $R$. officinalis L.) and oregano $(O$. onites L.) plants were added to pistachio puree at three different concentrations (150, 300 and $600 \mathrm{ppm}$ ) on the basis of oil content of puree. BHA was added as $150 \mathrm{ppm}$ for the comparison since 300 and $600 \mathrm{ppm}$ exceeds the limit of usage BHA according to the regulation in the world. The control sample was also used to observe the effect of adding antioxidants on prolonging the shelf life of pistachio 
puree. All samples were tightly sealed in the glass jars and two parts of them were placed to incubators (Daihan WIG-150, Korea) at 25 and $40{ }^{\circ} \mathrm{C}$. Another part was stored in a cold room at $15{ }^{\circ} \mathrm{C}$ for analysis. The samples were taken at proper time intervals to observe chemical changes during storage.

2.2.3 Oil Extraction for Chemical Analysis

One hundred (100) grams of each sample was extracted with $300 \mathrm{~mL}$ of chloroform/methanol (2/1, $v / v)$ mixture at appropriate time intervals. After mixing the sample and solvent with a glass rod, the mixture was waited 1-2 hours in dark place and filtered through Whatman No. 42 filter paper by twice. The residue was re-extracted twice by the same solvent; the filtrates from three extractions were combined. The solvent-oil mixture was then passed through over anhydrous sodium sulfate placed over a filter paper in a funnel. The solvent was removed using a rotary evaporator (Heidolph Laborota 4000 Efficient, Germany) at $40{ }^{\circ} \mathrm{C}$. The resulting oil was stored at $4{ }^{\circ} \mathrm{C}$ until use [8].

\subsubsection{Chemical Analysis}

Moisture Content Determination. The moisture content was determined by the oven method according to the official method of analysis [9]. The measurements were carried out in triplicate.

Protein Determination. The protein content was determined by the Kjeldahl method. The nitrogen rate in samples was measured, the obtained number for the sample was multiplied in protein factor 6.25 and the amount of protein in sample was obtained according to the official method of analysis [9]. The measurements were carried out in triplicate.

Oil Content Determination. The oil content of pistachio kernel was determined according to TS 973 EN ISO 659 using solvent extractor (Ser 148-6, Velp Scientifica, Italy) [10]. The measurements were carried out in triplicate.

Fatty Acid Composition of Pistachio Puree Oil. The fatty acid composition of pistachio puree was analyzed on Agilent GC7890A gas chromatography equipped with a flame ionization detector and capillary column, $50 \mathrm{~m}$ in length and $0.25 \mathrm{~mm}$ in diameter according to the method of International Olive Oil Council [11].

Peroxide Value and Free Fatty Acid Value Determination. The peroxide value (PV) was measured according to British standards [12] and free fatty acid (FFA) value was analyzed according to the method described by Bozkurt and Göğüş [13].

Oxidative Measurement (Rancimat Method). A metrohm Rancimat model 743 (Herisau, Switzerland) capable of operating over a temperature range of $50-220{ }^{\circ} \mathrm{C}$ was used in this study. The glassware was rigorously cleaned between each run to avoid any contamination that would catalyze the peroxidation. The tubes were cleaned with acetone after each run and then washed off with washing liquid in hot water. The washed tubes were rinsed with distilled water and dried in the oven. Measuring vessels, electrodes, and connecting tubes were cleaned several times with alcohol and distilled water.

Determination of the oxidative stability of pistachio oil by the Rancimat method was carried. A stream of air was bubbled into $3 \mathrm{~g}$ of oil samples in a reaction vessel placed in an electric heating block. Effluent air containing volatile organic acids from the oil sample was collected in a measuring vessel containing distilled water $(60 \mathrm{~mL})$. The conductivity of water was measured automatically as oxidation proceeded. Filtered, cleaned, dried air was allowed to bubble through the hot oil at rates of $20 \mathrm{~L} / \mathrm{h}$. The induction time of the oil samples was automatically recorded at 100,110 , and $120^{\circ} \mathrm{C}$ for each sample that was roasted at different temperatures. For each time studied, eight samples were accommodated in the equipment and analyzed simultaneously [14].

\subsection{Statistical Analysis}

The results were compared by the multifactor analysis of variance (multifactor ANOVA) to test for significant differences. Means of the groups were 
compared using Duncan's multiple range test using a SPSS statistical packet (Version 21, 2012, Polar Engineering and Consulting, Nikiski, USA). Differences among sample means were reported to be significant when $p<0.05$ and the Microsoft Office program was used for drawing plots.

\section{Results and Discussions}

\subsection{Characteristics of Pistachio Puree}

Some characteristics of pistachio puree were presented in Table 1. The moisture content of pistachio puree was $1.36 \%$ on wet basis. There is no available standard for the composition of pistachio puree but according to Turkish standard of hazelnut puree (TS 10938), similar processed product; it should be less than 3\%. Also from the producer side, it should be less than $2 \%$ based on customer demand [15]. The protein content of the sample was $20.5 \%$. In a study carried out by Ref. [16], the number of protein cultivars of Uzun, Kırmızı, Siirt, Ohadi and Halabi pistachios was reported $22.67 \%, 20.93 \%, 22.45 \%$, $23.62 \%$, and $20.18 \%$, respectively. It is possible that low amounts of protein obtained in this study have been influenced by the kind of pistachio nuts. The amount of oil was obtained at $48 \%$. The result in the study was less than previous studies obtained by Refs. $[16,17]$ due to kind of pistachio nut. In the fatty acid composition, main fatty acids were oleic acid $71.05 \%$, linoleic acid $16.55 \%$ and palmitic acid $8.52 \%$ that are relatively consistent with the results of other studies $[17,18]$.

\subsection{Compositions of Essential Oils}

The compositions of oregano (O. onites L.) and rosemary ( $R$. officinalis L.) essential oils were present in Tables 2 and 3, respectively. The composition was

Table 1 Composition of pistachio puree.

\begin{tabular}{|c|c|}
\hline Properties & Amount \\
\hline Moisture content (\% wb.) & 1.36 \\
\hline Protein $(\%$ wb. $)$ & 20.50 \\
\hline Fat (\% wb.) & 48.00 \\
\hline \multicolumn{2}{|l|}{ Fatty acid composition (\%) } \\
\hline Caproic acid & $\mathrm{ND}^{*}$ \\
\hline Caprylic acid & $\mathrm{ND}^{*}$ \\
\hline Capric acid & $\mathrm{ND}^{*}$ \\
\hline Lauric acid & $\mathrm{ND}^{*}$ \\
\hline Myristic acid & 0.10 \\
\hline Palmitic acid & 8.52 \\
\hline Palmitoleic acid & 0.52 \\
\hline Margaric acid & $\mathrm{ND}^{*}$ \\
\hline Heptadecanoic acid & 0.07 \\
\hline Stearic acid & 1.88 \\
\hline Oleic acid & 71.05 \\
\hline Linoleic acid & 16.55 \\
\hline Linolenic acid & 0.34 \\
\hline Arachidic acid & 0.19 \\
\hline Eicosanoic acid & 0.49 \\
\hline Behenic acid & 0.01 \\
\hline Erucic acid (C22:1) & 0.01 \\
\hline Erucic acid (C22:2) & 0.01 \\
\hline Ligroceric acid & 0.04 \\
\hline Nervonic acid & 0.02 \\
\hline
\end{tabular}

* Related fatty acids were not detected (ND). 
Table 2 The compositions of oregano $(O$. onites $L$.) essential oil.

\begin{tabular}{ll}
\hline Components & Amount (\%) \\
\hline Cis-Salvene & 6.4 \\
$\alpha$-Thujene & 1.1 \\
Myrcene & 1.4 \\
Y-Terpinene & 4.2 \\
p-Cymene & 2.6 \\
Trans-sabinene hydrate & 1.1 \\
Linalool & 10.2 \\
Linalyl acetate & 1.2 \\
$\beta$-Bisabolene & 3.7 \\
Thymol & 1.6 \\
Carvacrol & 56.3 \\
$\beta$-caryophyllene & 2.4 \\
Borneol & 1.0 \\
Germacrene D & 1.0 \\
Total & 94.2 \\
\hline
\end{tabular}

$*$ Values $<1 \%$ not included.

Table 3 The compositions of rosemary (R. officinalis L.) essential oil.

\begin{tabular}{ll}
\hline Components & Amount (\%) \\
\hline$\alpha$-Pinene & 14.0 \\
Camphene & 4.3 \\
$\beta$-Pinene & 4.5 \\
$\delta$-3-Carene & 1.2 \\
Myrcene & 2.1 \\
Limonene & 3.5 \\
1.8-Cineole & 25.8 \\
Y-Terpinene & 1.3 \\
p-Cymene & 1.5 \\
Camphor & 6.8 \\
Linalool & 2.1 \\
Isopinocamphone & 1.2 \\
Bornyl acetate & 2.3 \\
Terpinen-4-ol & 1.5 \\
$\beta$-Caryophyllene & 5.0 \\
$\alpha$-Terpineol & 1.6 \\
Bomeol & 7.3 \\
Verbenone & 2.0 \\
Total* & 88.0 \\
\hline
\end{tabular}

$*$ Values $<1 \%$ not included.

analyzed by Agilent 7890 A GC and Agilent 5975 C VL MSD device. The results are relatively consistent with the results of other studies [19-23].

\subsection{Preliminary Determination of Antioxidant Activity}

The Rancimat test is a very easy and inexpensive method, which requires small sample volumes and achieves reproducible results. Although this technique has been questioned, it is commonly used in the food industry and governmental analytical laboratories. Table 4 gives the related antioxidant activity index (AAI) of pistachio oils with the essential oils added.

The higher the induction period of the pistachio oil 
with the essential oils added, compared with the control (pure pistachio oil), the better the antioxidant activity of that compound. The antioxidant activity index, as determined by the Rancimat method, decreased in the order: BHA > rosemary ( $R$. officinalis L.) essential oil > oregano (O. onites L.) essential oil.

According to this method, oregano and rosemary essential oils showed antioxidant activity, less than the activity of synthetic antioxidant. At the maximum concentration, rosemary essential oil showed the highest $(p<0.05)$ antioxidant activity index $(2.25)$ of all the essential oils analyzed. At all concentrations $(150,300$ and $600 \mathrm{ppm})$ oregano essential oils showed the lowest $(p<0.05)$ antioxidant activity indices.

\subsection{Oxidative Induction Time (OIP) of Pistachio Puree} Samples with or without Antioxidants at Different Temperatures

Oxidative stability is an important parameter for the quality assessment of fats and oils. Autoxidation is affected by atmospheric oxygen and the oxidation process proceeds via free radical reactions involving unsaturated fatty acids [24]. The OIP of pistachio puree samples with or without antioxidants at different temperatures is presented in Table 5 .

The induction time of pistachio puree oil was 26.22 hours at $110{ }^{\circ} \mathrm{C}$. The induction time of puree oil significantly increased to 50.34 (BHA-150 ppm), 39.84 (RO-150 ppm), 45.72 (RO-300 ppm), 54.79 (RO-600 ppm), 27.66 (OO-150 ppm), 29.03 (OO-300 ppm) and $34.48(\mathrm{OO}-600 \mathrm{ppm})$ as hour by adding antioxidants $(p<0.05)$. In samples with essential oils, there was a significant increase in induction time with an increasing concentration of essential oils $(p<0.05)$. The highest induction time $(54.79 \mathrm{~h})$ was observed in the sample which contains 600 ppm rosemary essential oil and the lowest one $(27.66 \mathrm{~h})$ in a sample containing $150 \mathrm{ppm}$ oregano essential oil. The effect of $150 \mathrm{ppm}$ BHA was lower than the $600 \mathrm{ppm}$ rosemary essential oil in lowering the oxidation rate whereas it was higher than other concentrations of both essential oils.

Table 4 Antioxidant activity of rosemary, oregano essential oils and BHA at $120^{\circ} \mathrm{C}$.

\begin{tabular}{llll}
\hline Antioxidants types & \multicolumn{2}{c}{ AAI } \\
\cline { 2 - 4 } & $150 \mathrm{ppm}$ & $300 \mathrm{ppm}$ & $600 \mathrm{ppm}$ \\
\hline Rosemary & $1.60^{\mathrm{aB}}$ & $1.95^{\mathrm{abB}}$ & $2.25^{\mathrm{bB}}$ \\
Oregano & $1.23^{\mathrm{aA}}$ & $1.33^{\mathrm{aA}}$ & $1.43^{\mathrm{aA}}$ \\
BHA & $2.04^{\mathrm{aC}}$ & $2.30^{\mathrm{aB}}$ & $2.75^{\mathrm{bC}}$ \\
\hline
\end{tabular}

Means followed by the same small letter within same line are not significantly different at $p<0.05$ significance level according to Duncan's multiple range test.

Means followed by the same capital letter within same column are not significantly different at $p<0.05$ significance level according to Duncan's multiple range test.

Table 5 The OIP of pistachio puree samples with or without antioxidants at different temperature.

\begin{tabular}{|c|c|c|c|c|}
\hline \multirow{2}{*}{ Antioxidant type } & \multirow{2}{*}{ Amount (ppm) } & \multicolumn{3}{|c|}{ Temperature $\left({ }^{\circ} \mathrm{C}\right)$} \\
\hline & & 110 & 120 & 130 \\
\hline \multirow[t]{3}{*}{ Rosemary (R. officinalis L.) } & 150 & $39.84^{\mathrm{dA}}$ & $22.44^{\mathrm{cB}}$ & $10.52^{\mathrm{cC}}$ \\
\hline & 300 & $45.72^{\mathrm{eA}}$ & $23.94^{\mathrm{dB}}$ & $12.03^{\mathrm{dC}}$ \\
\hline & 600 & $54.79^{\mathrm{gA}}$ & $27.32^{\mathrm{fB}}$ & $12.85^{\mathrm{eC}}$ \\
\hline \multirow[t]{3}{*}{ Oregano (O. onites L.) } & 150 & $27.66^{\mathrm{abA}}$ & $14.30^{\mathrm{aB}}$ & $7.31^{\mathrm{bC}}$ \\
\hline & 300 & $29.03^{\mathrm{bA}}$ & $13.73^{\mathrm{aB}}$ & $6.32^{\mathrm{aC}}$ \\
\hline & 600 & $34.48^{\mathrm{cA}}$ & $17.46^{\mathrm{bB}}$ & $7.31^{\mathrm{bC}}$ \\
\hline BHA & 150 & $50.34^{\mathrm{fA}}$ & $25.87^{\mathrm{eB}}$ & $12.08^{\mathrm{deC}}$ \\
\hline Control & 0 & $26.22^{\mathrm{aA}}$ & $13.23^{\mathrm{aB}}$ & $6.68^{\mathrm{abC}}$ \\
\hline
\end{tabular}


The induction time of pistachio puree oil was 13.23 hours at $120{ }^{\circ} \mathrm{C}$. The induction time of puree oil significantly increased to 25.87 (BHA-150 ppm), 22.44 (RO-150 ppm), 23.94 (RO-300 ppm), 27.32 (RO-600 ppm), 14.3 (OO-150 ppm), 13.73 (OO-300 ppm) and 17.46 (OO-600 ppm) as hour by adding antioxidants $(p<0.05)$. In samples with essential oils, there was a significant increase in induction time with increasing concentration of essential oils $(p<0.05)$. The highest induction time (27.32 h) was observed in the sample which contains 600 ppm rosemary essential oil and the lowest one (13.73 h) in a sample containing $150 \mathrm{ppm}$ oregano essential oil. The effect of again 150 ppm BHA was lower than the $600 \mathrm{ppm}$ rosemary essential oil in lowering the oxidation rate whereas it was higher than other concentrations of both essential oils.

The induction time of pistachio puree oil was 6.68 hours at $130{ }^{\circ} \mathrm{C}$. The induction time of puree oil significantly increased to 12.08 (BHA-150 ppm), 10.52 (RO-150 ppm), 12.03 (RO-300 ppm), 12.85 (RO-600 ppm), 7.31 (OO-150 ppm), and 7.31 (OO-600 ppm) as hour by adding antioxidants $(p<$ $0.05)$. In samples with essential oils, there was a significant increase in induction time with increasing concentration of essential oils except for $300 \mathrm{ppm}$ oregano essential oils added sample $(p<0.05)$. The highest induction time $(12.85 \mathrm{~h})$ was observed in the sample which contains 600 ppm rosemary essential oil and the lowest one $(6.32 \mathrm{~h})$ in a sample containing 300 ppm oregano essential oil. The effect of $150 \mathrm{ppm}$ BHA was lower than the 600 ppm rosemary essential oil in lowering the oxidation rate whereas it was higher than other concentrations of both essential oils. The induction time of samples containing both essential oils and BHA was close or having less difference between each other at $130{ }^{\circ} \mathrm{C}$. It shows us that at $130{ }^{\circ} \mathrm{C}$ increasing concentration of essential oils above a level does not have any change in the induction time of pistachio puree samples.

The induction time of all pistachio puree oil samples was decreased by increasing the operating temperature of the Rancimat device (Fig. 1). As would expect, the increasing Rancimat operating temperature significantly decreased the OIP of the sample $(p<$ $0.05)$. These observations indicate that the conditions under which the oil sample oxidizes vary with temperature. Similar results were found by Ref. [14].

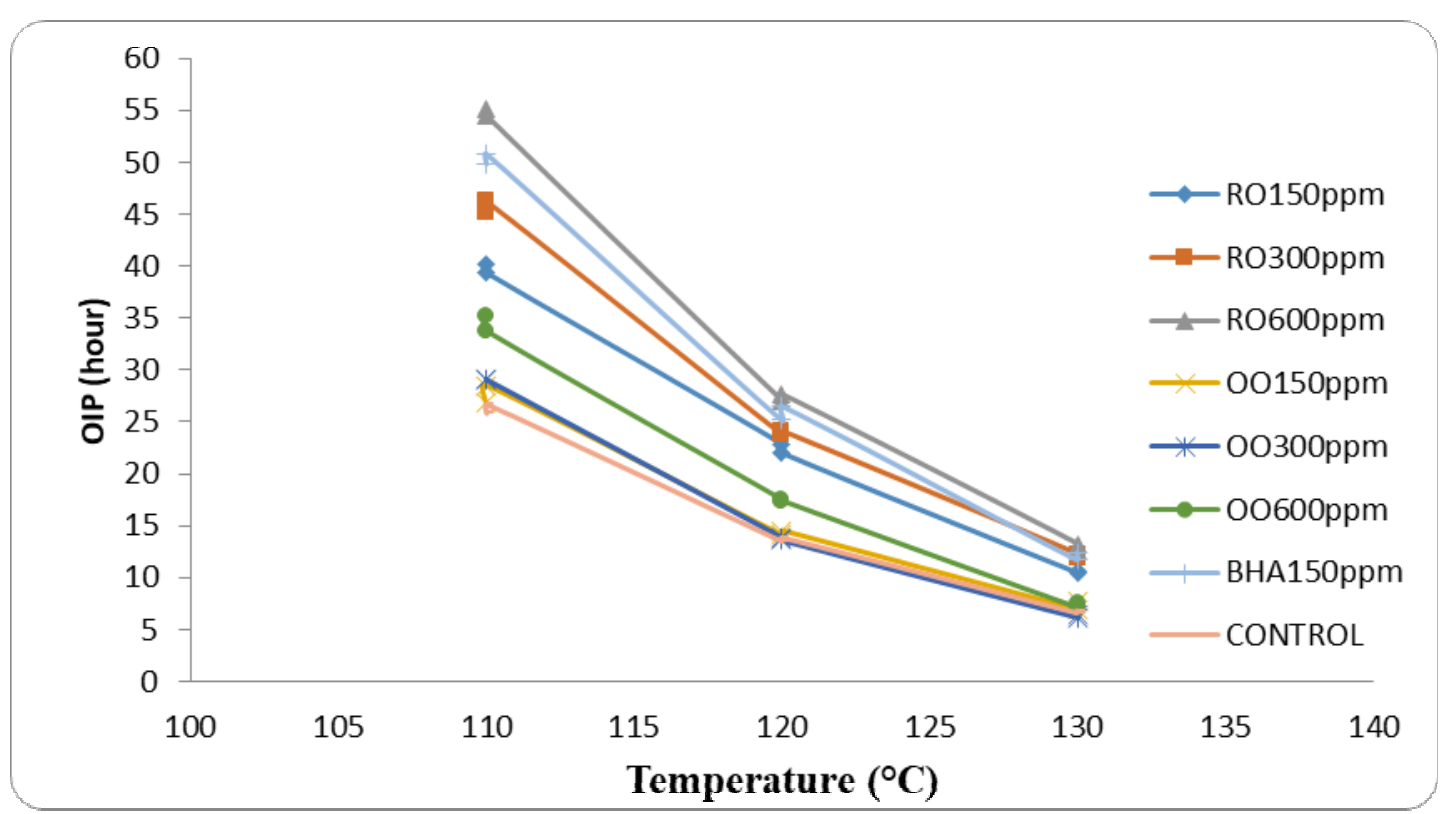

Fig. 1 Plot of OIP (hour) versus Rancimat operating temperature for samples with or without antioxidants. 


\subsection{Normal Storage Results of Pistachio Puree Samples}

\subsubsection{Peroxide Value (PV) Changes during Storage}

Lipid oxidation involves the continuous formation of hydroperoxides as primary oxidation products that may break down to a variety of nonvolatile and volatile secondary products. The formation rate of hydroperoxides outweighs their rate of decomposition during the initial stage of oxidation, and this becomes reversed at later stages. Therefore, the peroxide value $(\mathrm{PV})$ is an indicator of the initial stages of oxidative change. The PV represents the total hydroperoxide content and is one of the most common quality indicators of fats and oils during production and storage [25].

The changes in peroxide values of pistachio puree oil of samples with or without antioxidants during storage at $15{ }^{\circ} \mathrm{C}$ are shown in Fig. 2. In general, PV of all sample oils increased significantly $(p<0.05)$ with storage time. The PVs of pistachio puree oils were from 0.687 meq $\mathrm{O}_{2} / \mathrm{kg}$ (day 0) to 0.986 (month 8 ) in control, from 0.687 to 0.971 in $00-150 \mathrm{ppm}$, from 0.687 to 0.998 in OO-300 ppm, from 0.687 to 0.934 in OO-600 ppm, from 0.687 to 0.930 in RO- $150 \mathrm{ppm}$, from 0.687 to 0.912 in RO-300 ppm, from 0.687 to 0.873 in RO-600 ppm and from 0.687 to 0.900 in BHA-150 ppm added samples. After the third month, control sample oil had higher PV than the other sample oils except for OO-150 ppm and OO-300 ppm added sample oils. The PV increase was lower in RO, $\mathrm{OO}$ and BHA added samples than in control sample oil. Among pistachio puree oil of samples with essential oils and BHA, RO-600 ppm was lower in PV increase. The lowest increase among all samples was observed in the RO-600 ppm sample. But, statistically, there was no difference between the RO-600 ppm and BHA-150 ppm added samples according to the results of Duncan's multiple range test at $15{ }^{\circ} \mathrm{C}$.

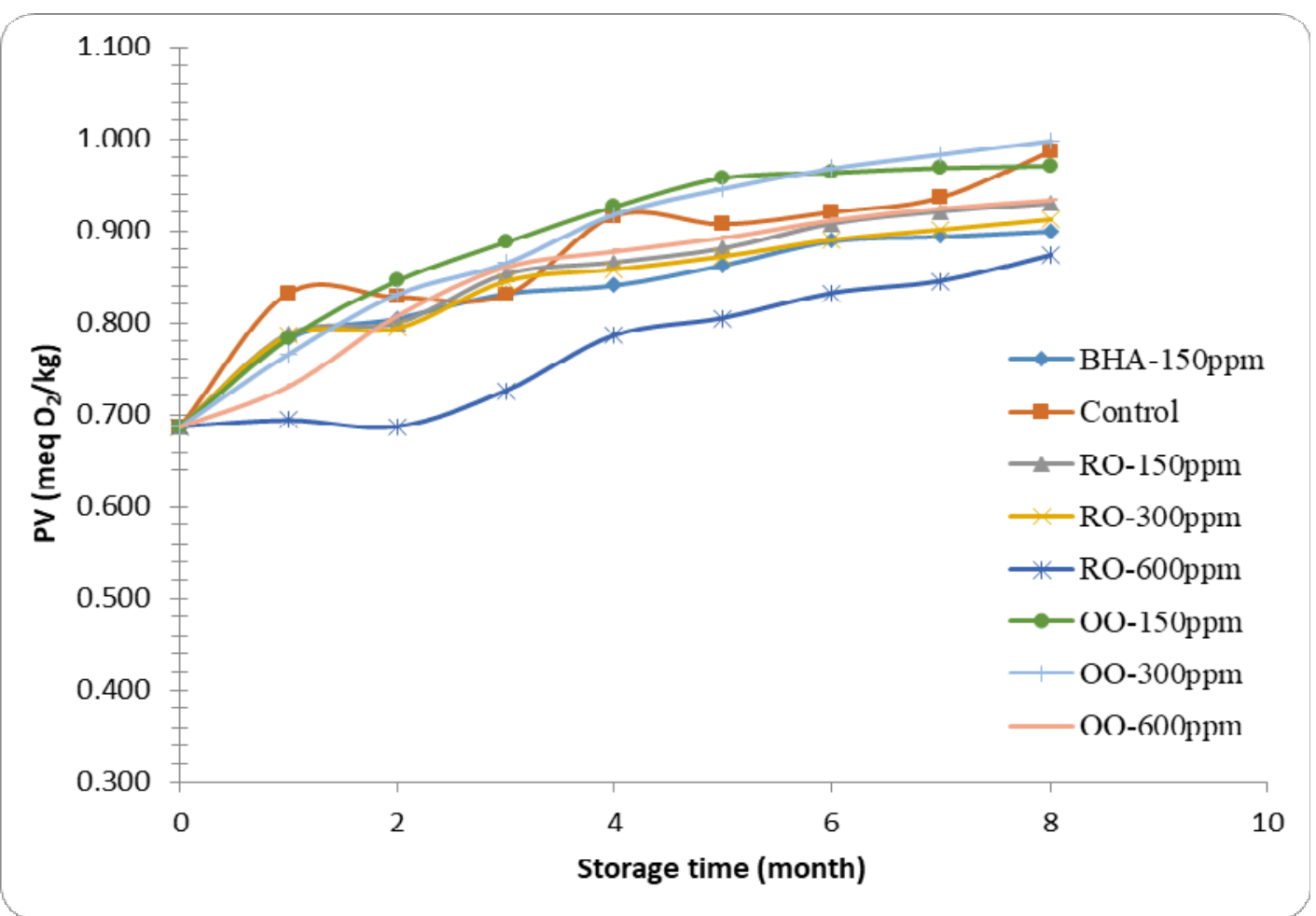

Fig. 2 Peroxide values (meq $\mathrm{O}_{2} / \mathrm{kg}$ ) from different pistachio puree oil of samples: pistachio puree control oil and pistachio puree oil of samples added with RO (R. officinalis L. essential oil), OO (O. onites L. essential oil) and BHA (butylated hydroxyanisole) at $15^{\circ} \mathrm{C}$. 
The changes in peroxide values of pistachio puree oil of samples with or without antioxidants during storage at $25^{\circ} \mathrm{C}$ are shown in Fig. 3. In general, PV of all sample oils increased significantly $(p<0.05)$ with storage time. The PVs of pistachio puree oils were from $0.687 \mathrm{meq} \mathrm{O}_{2} / \mathrm{kg}$ (day 0) to 1.233 (month 8) in control, from 0.687 to 1.224 in $\mathrm{OO}-150 \mathrm{ppm}$, from 0.687 to 1.116 in OO-300 ppm, from 0.687 to 0.989 in OO-600 ppm, from 0.687 to 0.966 in RO-150 ppm, from 0.687 to 0.934 in $\mathrm{RO}-300 \mathrm{ppm}$, from 0.687 to 0.893 in RO-600 ppm and from 0.687 to 0.916 in BHA-150 ppm added samples. After the third month, the control sample oil had higher PV than the other sample oils. The PV increase was lower in RO, OO and BHA added samples than in the control sample. Among pistachio puree oil of samples with essential oils and BHA, RO-600 ppm was lower in PV increase. The lowest increase among all samples was observed in the RO-600 ppm sample.

The changes in peroxide values of pistachio puree oil of samples with or without antioxidants during storage at $40{ }^{\circ} \mathrm{C}$ are shown in Fig. 4. In general, PV of all sample oils increased significantly $(p<0.05)$ with storage time. The PVs of pistachio puree samples were from 0.687 meq $\mathrm{O}_{2} / \mathrm{kg}$ (day 0) to 2.936 (month 8) in control, from 0.687 to 2.787 in OO-150 ppm, from 0.687 to 2.565 in OO-300 ppm, from 0.687 to 2.428 in OO-600 ppm, from 0.687 to 2.420 in RO-150 ppm, from 0.687 to 2.350 in RO-300 ppm, from 0.687 to 2.016 in RO-600 ppm and from 0.687 to 2.115 in BHA-150 ppm added samples. Generally, after the third month, control sample oil had higher PV than the other sample oils. The PV increase was lower in RO, OO and BHA added samples than in the control sample. Among pistachio puree oil of samples with essential oils and BHA, RO-600 ppm was lower in PV increase. The lowest increase in PV among all samples was observed in the RO-600 ppm sample.

These results indicate that pistachio puree oil of samples with $R$. officinalis L. essential oil and $O$. onites L. essential oil had better resistance to lipid oxidation than control samples. In addition, RO-600

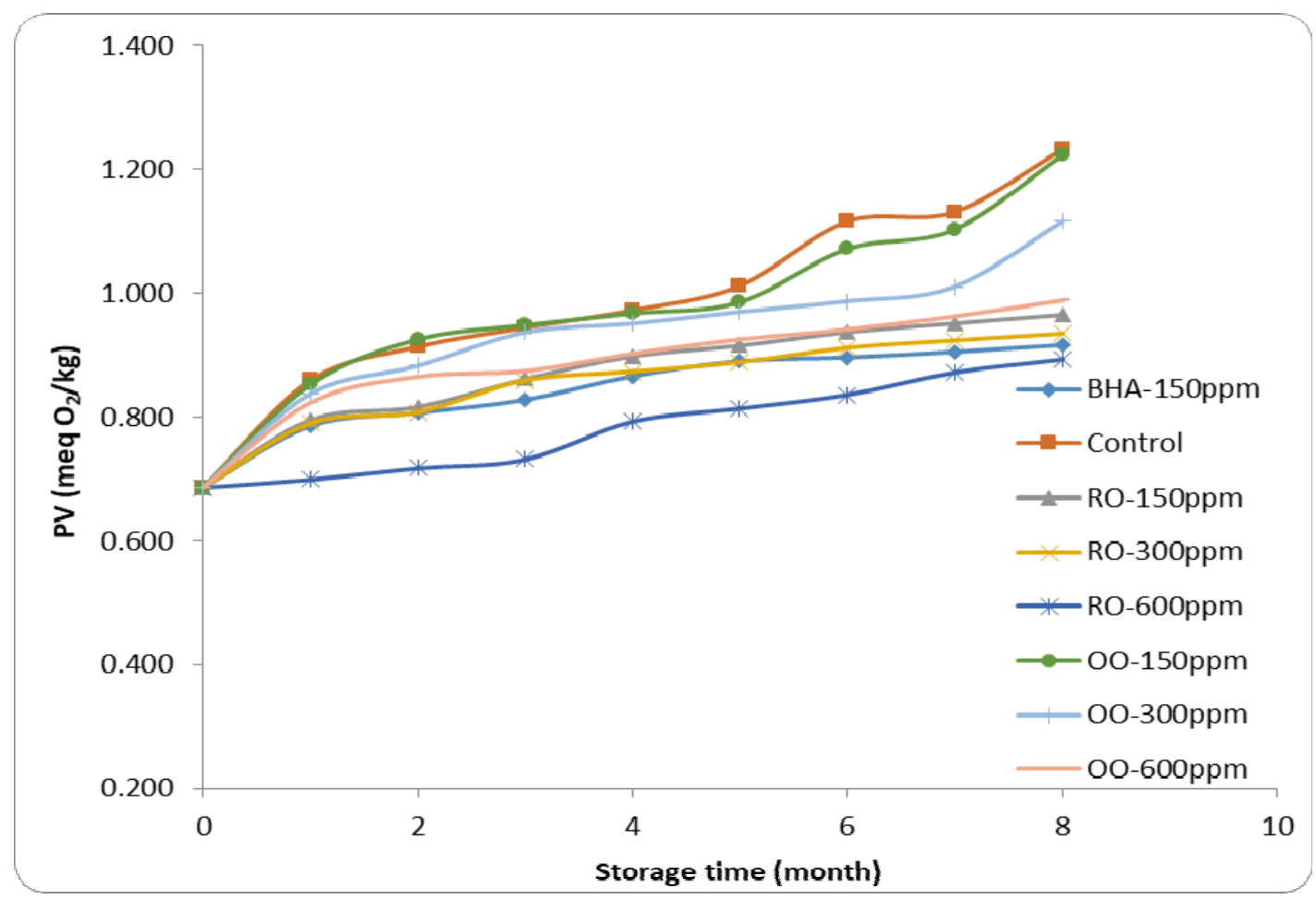

Fig. 3 Peroxide values (meq $\mathrm{O}_{2} / \mathrm{kg}$ ) from different pistachio puree oil of samples: pistachio puree control oil and pistachio puree oil of samples added with RO (R. officinalis L. essential oil), OO (O. onites L. essential oil) and BHA (butylated hydroxyanisole) at $25^{\circ} \mathrm{C}$. 


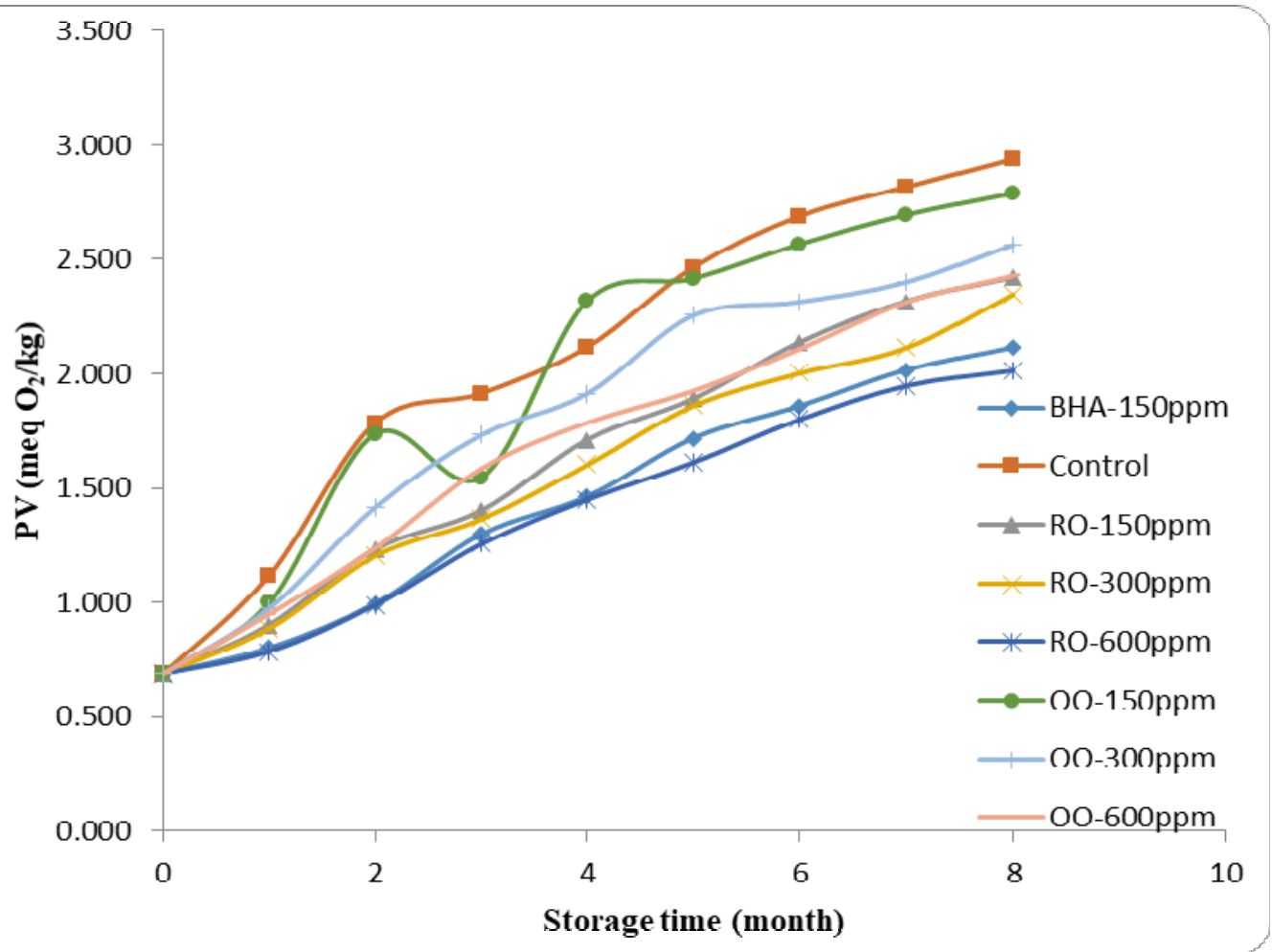

Fig. 4 Peroxide values (meq $\mathrm{O}_{2} / \mathbf{k g}$ ) from different pistachio puree oil of samples: pistachio puree control oil and pistachio puree oil of samples added with RO ( $R$. officinalis L. essential oil), OO (O. onites L. essential oil) and BHA (butylated hydroxyanisole) at $40^{\circ} \mathrm{C}$.

ppm added sample showed the highest antioxidant activity that is very close to BHA-150 ppm added sample at all storage temperatures. Other researches [20, 26-31] observed antioxidant activity of oregano and rosemary essential oil measured by different methods. The antioxidant activity of rosemary essential oils and extracts has been associated with the presence of these monoterpenes ( $\alpha$-pinene, 1,8-cineole, and camphor) and phenolic components which break free radical chain reactions by hydrogen atom donation [32-34]. Several studies have reported about the oregano, its oils and extracts retard the lipid oxidation in different media that may be related to the presence of thymol and carvacrol [3, 26-28].

\subsubsection{FFA Value Changes during Storage}

Hydrolysis process in fats and oils results in the formation of FFAs, mono- and di-glycerides, and glycerol. This hydrolysis is a deterioration process of lipid and it can be estimated by measuring the FFAs [35].
The changes in FFA values of pistachio puree oil of samples with or without antioxidants during storage at $15^{\circ} \mathrm{C}$ are shown in Fig. 5. In general, the FFA of all sample oils increased significantly $(p<0.05)$ with storage time. The FFAs of pistachio puree oils were from 0.219 (\%) as oleic acid (day 0) to 0.576 (month 8) in control, from 0.219 to 0.529 in $\mathrm{OO}-150 \mathrm{ppm}$, from 0.219 to 0.468 in OO-300 ppm, from 0.219 to 0.459 in OO-600 ppm, from 0.219 to 0.446 in RO- $150 \mathrm{ppm}$, from 0.219 to 0.425 in RO-300 ppm, from 0.219 to 0.321 in RO-600 ppm and from 0.219 to 0.413 in BHA-150 ppm added samples. The FFA increase was lower in $\mathrm{RO}, \mathrm{OO}$ and BHA added samples than in the control sample. Among pistachio puree oil of samples with essential oils and BHA, RO-600 ppm was lower in FFA increase. The lowest increase among all samples was observed in the RO-600 ppm sample.

The changes in FFA values of pistachio puree oil of samples with or without antioxidants during storage at $25^{\circ} \mathrm{C}$ are shown in Fig. 6. In general, the FFA of all 


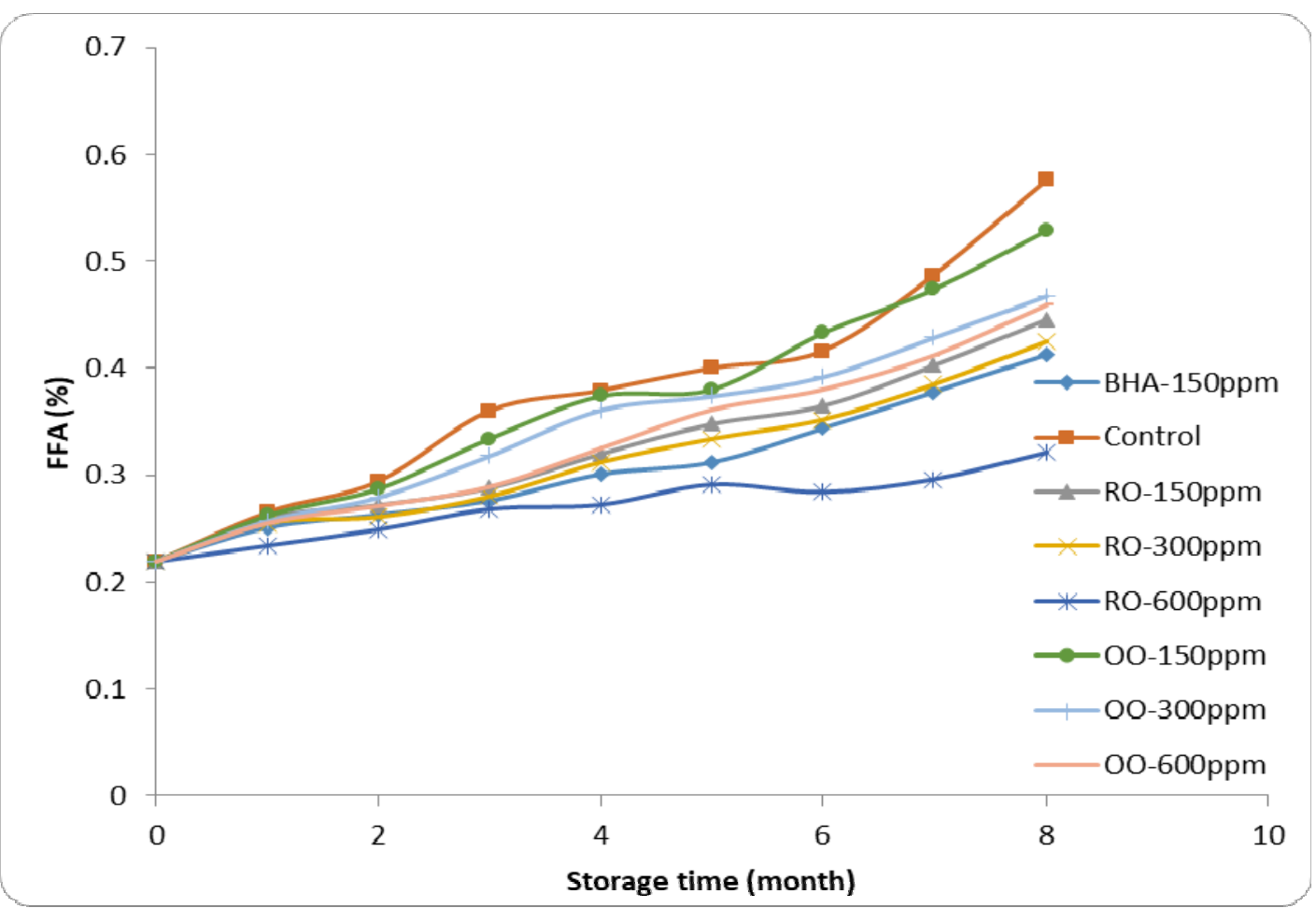

Fig. 5 Free fatty acid values (\%) from different pistachio puree oil of samples: pistachio puree control oil and pistachio puree oil of samples added with RO ( $R$. officinalis L. essential oil), OO (O. onites L. essential oil) and BHA (butylated hydroxyanisole) at $15{ }^{\circ} \mathrm{C}$.

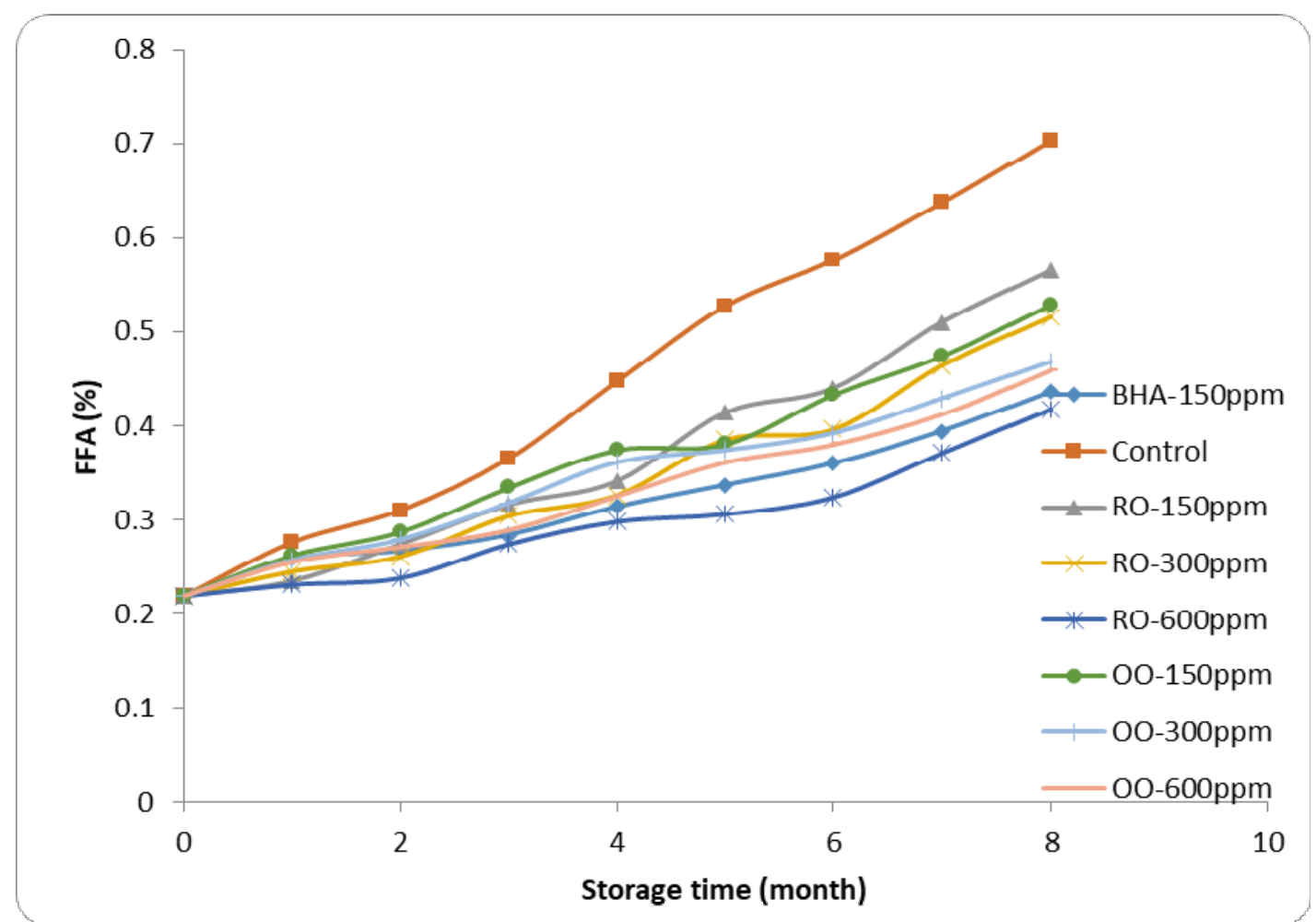

Fig. 6 Free fatty acid values (\%) from different pistachio puree oil of samples: pistachio puree control oil and pistachio puree oil of samples added with RO ( $R$. officinalis L. essential oil), OO (O. onites L. essential oil) and BHA (butylated hydroxyanisole) at $25^{\circ} \mathrm{C}$. 
sample oils increased significantly $(p<0.05)$ with storage time. The FFAs of pistachio puree oils were from $0.219(\%)$ as oleic acid (day 0) to 0.703 (month 8) in control, from 0.219 to 0.615 in OO- $150 \mathrm{ppm}$, from 0.219 to 0.584 in OO-300 ppm, from 0.219 to 0.571 in OO-600 ppm, from 0.219 to 0.565 in RO- $150 \mathrm{ppm}$, from 0.219 to 0.516 in RO-300 ppm, from 0.219 to 0.418 in RO-600 ppm and from 0.219 to 0.436 in BHA-150 ppm added samples. The FFA increase was lower in RO, OO and BHA added samples than in the control sample. Among pistachio puree oil of samples with essential oils and BHA, RO-600 ppm was lower in FFA increase. The lowest increase among all samples was observed in the RO-600 ppm sample.

The changes in free fatty acid values of pistachio puree oil of samples with or without antioxidants during storage at $40{ }^{\circ} \mathrm{C}$ are shown in Fig. 7. In general, the FFA of all oils increased significantly $(p<0.05)$ with storage time. The FFAs of pistachio puree oils were from $0.219(\%)$ as oleic acid (day 0) to 0.896 (month 8 ) in control, from 0.219 to 0.883 in OO-150 ppm, from 0.219 to 0.879 in OO-300 ppm, from 0.219 to 0.840 in OO-600 ppm, from 0.219 to 0.818 in RO-150 ppm, from 0.219 to 0.772 in RO-300 ppm, from 0.219 to 0.653 in RO-600 ppm and from 0.219 to 0.711 in BHA-150 ppm added samples. The FFA increase was lower in $\mathrm{RO}, \mathrm{OO}$ and BHA added samples than in the control sample. Among pistachio puree oil of samples with essential oils and BHA, RO-600 ppm was lower in FFA increase. The lowest increase among all samples was observed in the RO-600 ppm sample.

Ref. [36] reported that the addition of grounded leaves and flowers from the aromatic plants (rosemary, lavender, sage, lemon, and thyme) in olive oil caused a slight increase in FFA. Ref. [37] also found that the oregano essential oil addition in olive oil for different treatments did not increase the FFA.

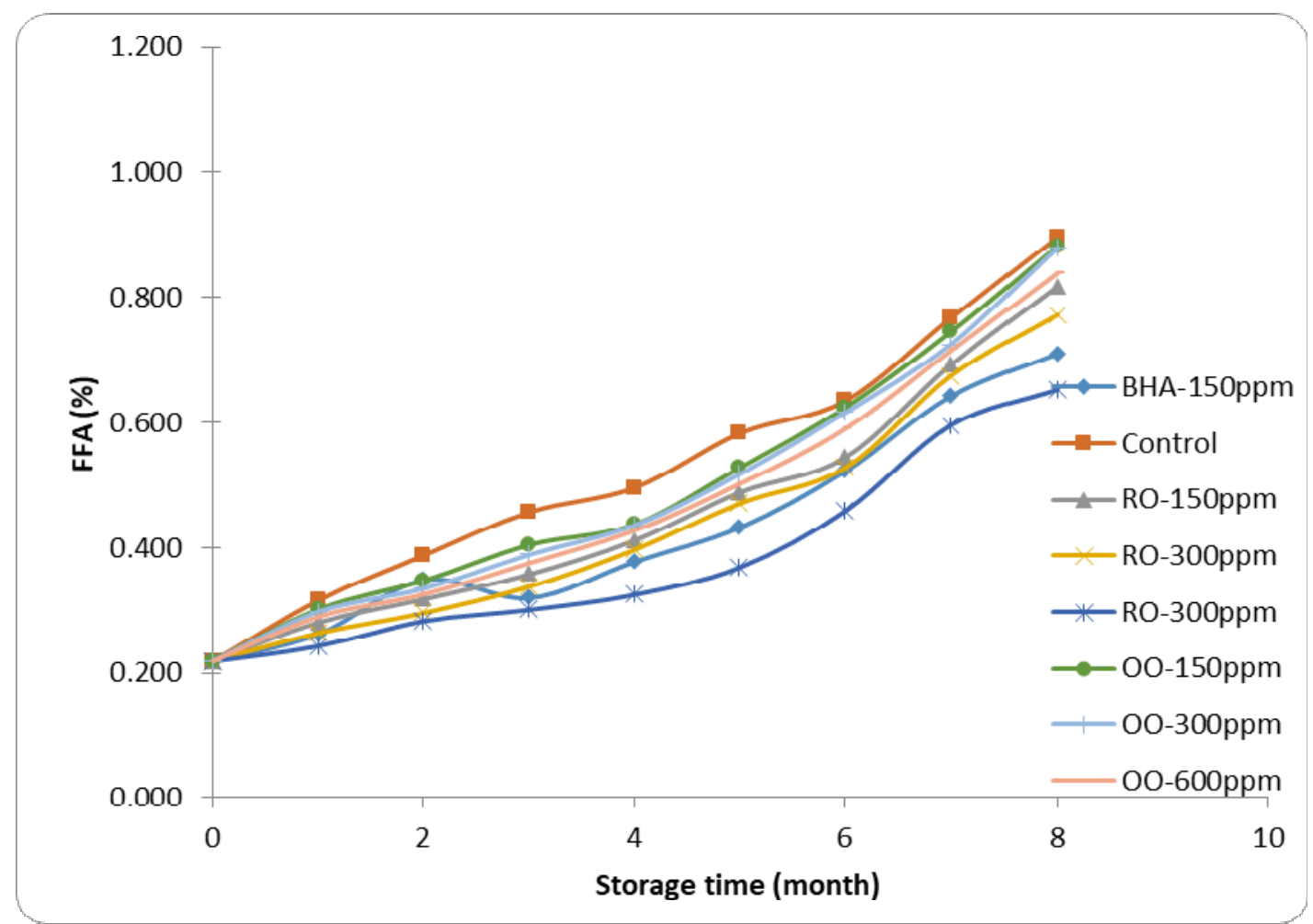

Fig. 7 Free fatty acid values (\%) from different pistachio puree oil of samples: pistachio puree control oil and pistachio puree oil of samples added with RO (R. officinalis L. essential oil), OO (O. onites L. essential oil) and BHA (butylated hydroxyanisole) at $40^{\circ} \mathrm{C}$. 
In general, PV and FFA of pistachio puree samples increased as the storage time progressed at all storage temperatures. However, the increases in $\mathrm{PV}$ values were much higher in samples stored at $40{ }^{\circ} \mathrm{C}(p<0.05)$ as expected since the oxidation mechanism slows down at lower temperatures [38]. A combination of low-temperature storage and the addition of antioxidants resulted in low peroxide values.

During the storage of the present study, increasing temperature also increases oil separation. Low oxidation rate in those samples also may be related to the prevention of oil phase separation and less exposure to oxygen in combination with the protective effect of antioxidant [39].

\section{Conclusion}

The results of the present work indicate that the addition of essential oils of rosemary and oregano on pistachio puree improves the stability of the product preventing lipid oxidation and development of rancid flavors. These antioxidant activities could be mainly associated with $\alpha$-pinene, 1,8-cineole, and camphor for rosemary and thymol and carvacrol for oregano essential oil. Therefore, these essential oils can be added as natural antioxidants in pistachio puree.

Rosemary essential oil showed a higher antioxidant effect on the stability of this product with respect to the synthetic antioxidant, BHA, and oregano essential oil during accelerated conditions and normal storage conditions. The highest antioxidant effect was observed between the sample with 600 ppm rosemary essential oil and 150 ppm BHA added sample at all conditions. Synthetic antioxidants such as BHA, butylated hydroxytoluene (BHT) and propyl gallate (PG) are used in many foods to prevent rancidity but there is a growing concern for the potential health hazards because of their synthetic conditions. Therefore, natural antioxidants from essential oil can be replaced by synthetic ones.

The PV and FFA results did not reach the limit of pistachio puree which is 2 meq $\mathrm{O}_{2} / \mathrm{kg}$ for $\mathrm{PV}$ and $1(\%)$ like oleic acid for FFA at the end of eight-month storage time except for $40{ }^{\circ} \mathrm{C}$. Therefore, it should be better storage of pistachio puree at 15 and $25^{\circ} \mathrm{C}$ than $40{ }^{\circ} \mathrm{C}$ to get a lower oxidation rate.

As indicated in present study, using natural antioxidants in lipid or lipid-containing foods increases the shelf life of the product. However, the intense herb flavor may limit some applications for food products. On the contrary, for the increase in shelf-life, aspects such as toxic or pathogenic activity and intense herb flavor should be considered.

\section{Acknowledgments}

Authors would like to thank Asim Samli Agricultural Products Import, Export \& Trading Inc. for their help and support during Rancimat experiments. This research did not receive any specific grant from funding agencies in the public, commercial, or not-for-profit sectors.

\section{Conflict of Interest}

Authors declare that there are no present or potential conflicts of interest among them and other people or organizations that could inappropriately bias their work.

\section{References}

[1] FAO. 2011. "FAOSTAT Online Statistical Service." Food and Agriculture Organization of the United Nations. Accessed June 2011. http://faostat.fao.org/.

[2] Omid, M., Baharlooei, A., and Ahmadi, H. 2009. "Modeling Drying Kinetics of Pistachio Nuts with Multilayer Feed-Forward Neural Network." Drying Technology 27 (10): 1069-77.

[3] Viuda-Martos, M., Navajas, Y. R., Zapata, E. S., Lopez, J. F., and Alvarez, J. A. 2009. "Antioxidant Activity of Essential Oils of Five Spice Plant Widely Used in Mediterranean Diet." Flavour and Fragnance Journal 25: 13-9.

[4] Daker, M., Abdullah, N., Vikineswary, S., Goh, P. C., and Kuppusamy, U. R. 2008. "Antioxidant from Maize and Maize Fermented by Marasmiellus sp. as Stabiliser of Lipid-Rich Foods." Food Chemistry 107 (3): 1092-8.

[5] Gramza, A., and Korczak, J. 2005. "Tea Constituents 
(Camellia sinensis L.) as Antioxidants in Lipid Systems." Trends in Food Science \& Technology 16 (8): 351-8.

[6] Kulisic, T., Radonic, A., Katalinic, V., and Milos, M. 2004. "Use of Different Methods for Testing Antioxidative Activity of Oregano Essential Oil." Food Chemistry 85 (4): 633-40.

[7] Singh, G., Marimuthu, P., De Heluani, C. S., and Catalan, C. 2005. "Chemical Constituents and Antimicrobial and Antioxidant Potentials of Essential Oil and Acetone Extract of Nigella sativa Seeds." Journal of the Science of Food and Agriculture 85 (13): 2297-306.

[8] Miraliakbari, H., and Shahidi, F. 2008. "Oxidative Stability of Tree Nut Oils." Journal of Agricultural and Food Chemistry 56: 4751-9.

[9] AOAC. 1995. Official Methods of Analysis. 16th ed., Arlington, VA: Association of Official Analytical Chemists.

[10] Turkish Standard. 2000. Oilseeds—Determination of Oil Content (Reference Methods). Türk Standartları Enstitüsü, Bakanlıklar, Ankara.

[11] COI. 2001. International Olive Oil Council. COI/T.20/Doc. No.10/Rev 1.

[12] BSI 684. 1987. Methods of Analysis Fats and Fatty Oils. British Standard Institution, London.

[13] Bozkurt, H., and GöğüĢ, F. 2004. Free Fatty Acid Determination of Oils. Food Quality Control Laboratory Book.

[14] Farhoosh, R. 2007. "The Effect of Operational Parameters of the Rancimat Method on the Determination of the Oxidative Stability Measures and Shelf-Life Prediction of Soybean Oil." Journal of the American Oil Chemists'Society 84 (3): 205-9.

[15] Anonyms. 2010. Asim Saml 1 Agricultural Products Export, Import and Trading, SA Pistachio Puree Production Method.

[16] Küçüköner, E., and Yurt, B. 2003. "Some Chemical Characteristics of Pistachia vera Varieties Produced in Turkey." European Food Research and Technology 217: 308-10.

[17] Okay, Y. 2002. "The Comparision of Some Pistachio Cultivars Regarding Their Fat, Fatty Acids and Protein Content." Gartenbauwissenschaft 67 (3): 107-13.

[18] Maskan, M., and Karatas, S. 1999. "Storage Stability of Whole-Split Pistachio Nuts (Pistacia vera L.) at Various Conditions." Food Chemistry 66: 227-33.

[19] Bayrak, A., and Akgül, A. "1989. Biberiye bitkisinin uçucu yağ komposizyonu üzerinde araĢtırma." Gıda Sanayi Dergisi 5: 20-2.

[20] Wang, W., Wu, N., Zu, Y. G., and Fu, Y. J. 2008. "Antioxidative Activity of Rosmarinus officinalis L. Essential Oil Compared to Its Main Components." Food Chemistry 108: 1019-22.
[21] Jiang, Y., Wu, N., Fu, Y. J., Wang, W., Luo, M., Zhao, C. J., Zu, Y. G., and Liu, X. L. 2011. "Chemical Composition and Antimicrobial Activity of the Essential Oil of Rosemary." Environmental Toxicology and Pharmacology 32 (1): 63-8.

[22] Yaldiz, G., Sekeroglu, N., Özgüven, M., and Kirpik, M. 2005. "Seasonal and Diurnal Variability of Essential Oil and Its Components in Origanum onites L. Grown in the Ecological Conditions of Cukurova." Grasas y Aceites 56 (4): 254-8.

[23] Kacar, O., Göksu, E., and Azkan, N. 2006. "The Effect of Different Plant Densites on Some Agronomic and Quality Characteristics of Oregano (Origanum onites L.)." The Journal of Agricultural Faculty of Uludag University 2: 51-60.

[24] Wanasundara, P. K. J. P. D., and Shahidi, F. 2005. "Antioxidants: Science Technology and Applications." In Bailey's Industrial Oil and Fat Products, Vol. 6, 6th ed., edited by Shahidi, F., Hoboken, New Jersey: Wiley Interscience, 431-89.

[25] Shahidi, F., and Zhong, Y. 2005. "Lipid Oxidation: Measurement Methods." In Bailey's Industrial Oil and Fat Products, 6th ed., Vol. 6, edited by Shahidi, F., Hoboken, New Jersey: Wiley Interscience, 357-80.

[26] Bendini, A., Toschi, T. G., and Lercker, G. 2002. "Antioxidant Activity of Oregano (Origanum vulgare L.) Leaves." Italian Journal of Food Science 14 (1): 17-24.

[27] Cervato, G., Carabelli, M., Gervasio, S., Cittera, A., Cazzola, R., and Cestaro, B. 2000. "Antioxbdant Properties of Oregano (Origanum vulgare) Leaf Extracts." Journal of Food Biochemistry 24 (6): 453-65.

[28] Damechki, M., Sotiropoulou, S., and Tsimidou, M. 2001. "Antioxidant and Pro-oxidant Factors in Oregano and Rosemary Gourmet Olive Oils." Grasas y Aceites 52 (3-4): 207-13.

[29] Nepote, V., Mestrallet, M. G., Ryan, L., Conci, S., and Grosso N. R. 2006. "Sensorial and Chemical Changes in Honey Roasted Peanuts and Roasted Peanuts Stored under Different Temperatures." Journal of the Science of Food and Agriculture 86: 1057-63.

[30] Olmedo, R. H., Asensio, C., Nepote, V., Mestrallet, M. G., and Grosso, N. R. 2009. "Chemical and Sensory Stability of Fried-Salted Peanuts Flavored with Oregano Essential Oil and Olive Oil." Journal of the Science of Food and Agriculture 89: 2128-36.

[31] Özcan, M. M., and Arslan, D. 2011. "Antioxidant Effect of Essential Oils of Rosemary, Clove and Cinnamon on Hazelnut and Poppy Oils." Food Chemistry 129: 171-4.

[32] Aruoma, O. I., Halliwell, B., Aeschbach, R., and Löliger, J. 1992. "Antioxidant and Pro-oxidant Properties of Active Rosemary Constituents: Carnosol and Carnosic Acid." Xenobiotica 22 (2): 257-68. 
[33] Basaga, H., Tekkaya, C., and Acitel, F. 1997. "Antioxidative and Free Radical Scavenging Properties of Rosemary Extract." Lebensmittel-Wissenschaft und Technologie 30 (1): 105-8.

[34] Georgantelis, D., Blekas, G., Katikou, P., Ambrosiadis, I., and Dimitiros, J. F. 2007. "Effect of Rosemary Extract, Chitosan and $\alpha$-Tocopherol on Lipid Oxidation and Color Stability during Frozen Storage of Beef Burgers." Meat Science 75: 266-74.

[35] Gertz, C. 1996. "Chemical Changes of Oils and Fats at Elevated Temperatures." In Fat in the Diet, edited by Bell, B. M. Bridgwater, England: Barnes and Associates, pp. 15-21.

[36] Ayadi, M. A., Grati-Kamoun, N., and Attia, H. 2009.
"Physico-Chemical Change and Heat Stability of Extra Virgin Olive Oils Flavoured by Selected Tunisian aromatic Plants." Food and Chemical Toxicology 47 (10): 2613-9.

[37] Asensio, C. M., Nepote, V., and Grosso, N. R. 2011. "Chemical Stability of Extra-virgin Olive Oil Added with Oregano Essential Oil." Journal of Food Science 76: 445-50.

[38] Labuza, T. P. 1982. "Kinetics of Lipid Oxidation in Foods." CRC Critical Reviews in Food Technology 2: 355-405.

[39] Çapanoğlu, E., and Boyacığlu, D. 2008. "Improving the Quality and Shelf Life of Turkish Almond Paste." Journal of Food Quality 31: 429-45. 